Economic and Environmental Geology

Research Paper

\title{
Analysis of Domestic Aggregate Production of Korea in 2019 (III) - by Active Operations
}

\author{
Sei Sun Hong, Jin Young Lee ${ }^{*}$ \\ Geologic Research Center, Korea Institute of Geoscience and Mineral Resources, Daejeon 34132, Korea \\ *Corresponding author : jylee@kigam.re.kr

\section{ARTICLE INFORMATION} \\ Manuscript received 7 September 2021 \\ Received in revised form 8 October 2021 \\ Manuscript accepted 9 October 2021 \\ Available online 29 October 2021 \\ DOI : http://dx.doi.org/10.9719/EEG.2021.54.5.549

\section{Research Highlights} \\ - In 2019, a total of 872 operations produced crushed stone and \\ sand and gravel. \\ - Production by size of operation in 2019 indicate that about $50 \%$ of \\ total aggregates was produced by 81 operations reporting \\ production of more than 400 thousand $\mathrm{m}^{3}$. \\ - By province in 2019, Gyeongsangbuk-do had 149 active \\ operations, followed by Gyeonggi-do with 135, Gangwon-do with \\ 113, Gyeongsangnam-do with 92.
}

\begin{abstract}
In 2019, at 147 local governments, a total of 872 operations produced aggregates with 414 operations by permission, 458 operations by declaration except the marine operations. The leading aggregate sources were, in descending order of the number of operations, crushed, forest, land, washing, river aggregate. By aggregate type, gravel-only operations were slightly more than sand-only ones. By province, Gyeongsangbuk-do had 149 operations, followed by Gyeonggi-do with 135, Gangwon-do with 113, and Gyeongsangnamdo with 92 , Chungcheongbuk-do with 81 , and Jeollabuk-do with 70 . A review of production by size of operation indicated that about 23,100 thousand $\mathrm{m}^{3}\left(17.6 \%\right.$ of the total aggregate) was produced by 17 operations reporting production of more than 1 million $\mathrm{m}^{3}$, about 29,900 thousand $\mathrm{m}^{3}$ was produced by 44 operations reporting production between 500 and $<1,000$ thousand $\mathrm{m}^{3}$, about 60,000 thousand $\mathrm{m}^{3}$ was produced by 273 operations reporting production between 100 and $<200$ thousand $\mathrm{m}^{3}$, about 17,000 thousand $\mathrm{m}^{3}$ was produced by 409 operations reporting production between 10 and $<100$ thousand $\mathrm{m}^{3} .129$ operations that producted less than 10 thousand $\mathrm{m}^{3}$ accounted for $0.4 \%$ of total aggregate produced in Korea in 2019. Operations that produce more than $1 \mathrm{million}^{3}$ of aggregate was only from forest and crushed aggregate. The period of permission for aggregate producing based on permission is mostly less than 10 years, and in particular, for river and land aggregates, the permission period is very short, less than 2 years.
\end{abstract}

Keywords : active operation, production size, river aggregate, land aggregate, forest aggregate, crushed aggregate

Citation: Hong, S.S., Lee, J.Y. (2021) Analysis of Domestic Aggregate Production of Korea in 2019 (III) - by Active Operations. Korea Economic and Environmental Geology, v.54, p.549-560, doi:10.9719/EEG2021.54.5.549.

This is an Open Access article distributed under the terms of the Creative Commons Attribution Non-Commercial License (http://creativecommons.org/ licenses/by-nc/3.0) which permits unrestricted non-commercial use, distribution, and reproduction in any medium, provided original work is properly cited. pISSN 1225-7281; eISSN 2288-7962/C2021 The KSEEG. Printed by Hanrimwon Publishing Company. All rights reserved. 


\title{
연구논문
}

\section{9년도 국내 골재 수급 분석(III) - 채취장별 분석 -}

\author{
홍세선 · 이진영* \\ 한국지질자원연구원 지질연구센터 \\ *책임저자 : jylee@kigam.re.kr
}

\section{요 약}

2019년에는 바다골재를 제외한 전국 147 개 시군구의 872 개 채취장에서 골재를 생산하였다. 이 중 허가에 의한 골재 채취장은 414 개소이며, 신고에 의한 골재 채취장은 458 개소이다. 골재원별로 보면 선별파쇄골재가 가장 많은 채취장을 운영하며, 그 다음 으로 산림골재, 육상골재, 선별세척골재, 하천골재의 순으로 채취장의 수가 감소한다. 지역별로 보면 경상북도가 149 개소의 채 취장에서 골재를 생산하였으며 경기도는 135 개소, 강원도는 113 개소, 경상남도는 92 개소, 충청북도는 81 개소, 전라북도는 70 개 소에서 골재를 생산하였다. 채취장별 생산규모로 보면 100 만 $\mathrm{m}^{3}$ 이상의 골재를 생산한 채취장은 17 개소로서 생산량은 2019년 골재 생산량의 약 $17.6 \%$ 인 약 2,300 만 $\mathrm{m}^{3}$ 이다. 50 만 100 만 $\mathrm{m}^{3}$ 미만의 골재를 생산한 채취장은 44 개소로 생산량은 약 3 천만 $\mathrm{m}^{3}$, 10 만 50 만 $\mathrm{m}^{3}$ 미만의 채취장은 273 개소로 생산량은 약 6 천만 $\mathrm{m}^{3}, 1$ 만 10 만 $\mathrm{m}^{3}$ 미만의 채취장은 409 개소로 생산량은 1 천7백만 $\mathrm{m}^{3}$, 그리고 1 만 $\mathrm{m}^{3}$ 미만의 골재채취장은 129 개소로 생산량은 2019 년도 전체 골재생산량의 $0.4 \%$ 에 불과하다. 산림골재와 선별파쇄 에서만 100 만 $\mathrm{m}^{3}$ 이상의 골재를 생산하는 채취장이 운영된다. 골재허가에 의해 골재를 채취하는 하천, 육상, 산림골재에서의 허 가기간은 대체로 10 년 이내이며, 특히 하천골재와 육상골재는 2 년 이내로 매우 짧은 편이다.

주요어 : 골재채취장, 생산규모, 하천골재, 육상골재, 산림골재, 신고골재

\section{1. 서 론}

골재자원은 건설 및 토목에서는 가장 중요한 기본적인 자원으로 매년 약 1 억 5 천만 $\mathrm{m}^{3}$, 중량으로는 약 2 억4천만 $\mathrm{t}$ 내외의 막대한 양의 골재를 주택건설, 토목, 도로 등의 건설사업에 사용한다. 이는 전국민이 일인당 약 $3 \mathrm{~m}^{3}$ (약 5 t) 이상의 골재를 매년 사용하지만 골재의 특성상 국민 들이 직접 구매하여 사용하는 방식이 아닌 레미콘, 아스 콘 등 업체들 사이의, 즉 $\mathrm{B}$ to $\mathrm{B}$ 상거래 위주이므로 실 생활에서 골재의 중요성을 크게 인지하기는 어렵다. 그 러나 식량수급에서 쌀이 가장 중요한 자원인 것과 마찬 가지로 골재는 국민들의 주거생활에서 가장 필수적이며, 중요한 자원이다. 골재 수급의 불균형이 발생하면, 연쇄 적으로 레미콘 수급 불안정, 도로공사 및 건설공사의 지 연 등이 발생하여 레미콘, 아스콘 등 건설 관련산업에도 영향을 주게 되며, 이는 아파트, 대형빌딩 등의 건설산업 에 파급되어 주거생활에 불안정을 초래한다. 따라서 골 재의 수급현황을 파악하여 매년 골재의 수급이 원활하도 록 조정하는 것이 필요하다. 미국은 매년 미국지질조사 소에서 모래와 자갈, 부순골재의 두 부분으로 나누어 골 재 채취, 판매, 업체별 현황, 골재용 암석종류 분류, 용도
별 분류 등의 수급현황을 분석하고 있다(Willett, 2020(a), 2020(b)). 우리나라는 국토교통부에서 1993년 골재채취법 이 제정된 이후 매 5년마다 골재의 안정적 수급을 위해 골재수급기본계획(MLIT, 2014, 2018)을 수립하여 시행하 고 있으며 매년 각 시군단위의 골재채취통계를 집계하여 이를 골재자원정보관리시스템(www.agris.go.kr)에서 이를 관리하고 있다(MLIT, 2019). 골재자원의 수급통계현황에 대해서는 연도별(Hong et al., 2015), 전국시도단위(Hong and Lee, 2020), 시군구단위별(Hong and Lee, 2021)로 파 악한 바 있으나 골재 채취장별로 어떠한 채취패턴을 보 이는지에 대해서는 아직까지 연구된 바 없다. 이 연구에 서는 이러한 채취현황을 분석하여 매년 골재가 어떻게 채취되고, 어떤 골재원이 우세하며, 그 물량이 어느 정도 인가를 분석하여 골재의 수급안정에 기여하는 기초분석 자료를 제공하고자 한다.

\section{2. 분석방법}

이 연구에서는 광역시도, 시군구, 채취업체(채취장)의 3 단계로 구분하여 골재수급현황을 분석하고자 하였다. 분 석대상 광역시도는 서울 등 7 대 광역시와 경기도 등 9 개 
도, 그리고 세종특별자치시의 17 광역시도, 분석대상 시 군구는 서울특별시 25 개구, 인천광역시 10 개 군구, 경기 도 31 개 시군, 강원도 18 개 시군, 충청북도 11 개 시군, 대 전광역시 5 개 구, 충청남도 15 개 시군, 전라북도 9 개 시 군, 광주광역시 5 개 구, 전라남도 22 개 시군, 대구광역시 8 개 군구, 경상북도 23 개 시군, 부산광역시 16 개 군구, 울 산광역시 5 개 군구, 경상남도 18 개 시군, 제주특별자치도 2개 시, 그리 세종특별자치시 등 229개 시군구이다.

2019년도에 골재허가나 신고기간이 남아있는 채취장은 약 1,050 여개소 이다. 이들 중 2019년에 채취실적이 전 혀 없는(이미 채취물량을 소진하여) 채취장은 약 140여 개소이며, 그러고 바다골재 허가(EEZ 포함) 또는 신고채 취지역은 약 40 여개소 이다. 따라서 이번 골재현황분석 에서는 실적이 없거나(서울특별시, 광주광역시) 바다골재 채취장을 제외한 2019년에 골재채취실적 기록이 있는 하 천골재, 육상골재, 산림골재, 선별파쇄, 선별세척의 약 872 여개 채취장을 대상으로 골재원별, 권역별 채취분석을 실 시하였다. 이들 채취장들 중에는 동일 장소에서 채취하 지만 연장허가 또는 신규허가를 받은 경우 서로 다른 채 취장으로 간주하였으며, 같은 업체이더라도 골재원이 다 르거나 채취장소가 다른 경우는 서로 다른 채취장으로 간주하여 분석을 하였다. 따라서 이미 집계된 골재채취 현황과는 약간 상이할 수 있다.

\section{3. 권역별 골재채취현황}

수도권(서울, 인천, 경기도) : 2019년에 인천광역시에서 골재개발을 한 채취장은 17 개소로 모두 신고에 의한 채 취장이다(Table 1). 또한 모래만 채취한 채취장은 4개소, 자갈만 채취한 채취장은 10 개소, 그리고 모래와 자갈 모 두 채취한 채취장은 3 개소이다(Table 2). 인천광역시에서 서구가 9 개소의 채취장이 운영되고 있으며, 중구는 5 개 소, 그 밖에 계양구, 남동구, 강화군에서 각각 1 개소씩의 채취장이 운영되고 있다. 채취장들 중 100 만 $\mathrm{m}^{3}$ 이상의 골재를 개발한 채취장은 없으며, 50 만 100 만 $\mathrm{m}^{3}$ 미만의 골재채취는 4 개 채취장에서, 10 만 50 만 $\mathrm{m}^{3}$ 미만의 골재 채취는 9 개 채취장에서, 4 만 10 만 $\mathrm{m}^{3}$ 미만은 2 개 채취장 에서, 1 만 4 만 $\mathrm{m}^{3}$ 미만은 2 개 채취장에서, 1 만 $\mathrm{m}^{3}$ 미만의 채취장은 없다. 10 만 $\mathrm{m}^{3}$ 이상의 채취장이 13 개소로 인천 광역시 전체 채취장의 약 $40 \%$ 를 점유하는데 비해 골재 생산량은 인천광역시 총생산량의 약 $96 \%$ 를 점한다.

2019년에 경기도에서 골재개발을 한 채취장은 135 개소 이다(Table 1). 이 중 골재허가에 의한 채취장은 9개소이 며, 신고에 의한 채취장은 126 개소로 신고에 의한 골재 개발이 압도적으로 많은 편이다(Table 1). 허가에 의한 채 취장은 모두 산림골재 채석장이다. 또한 모래만 채취한 채취장은 31 개소, 자갈만 채취한 채취장은 55 개소, 그리

Table 1. Number of operation of aggregate in Korea in 2019, by province, by permission and declaration, and by sand and gravel

\begin{tabular}{|c|c|c|c|c|c|c|c|c|c|c|c|c|c|c|c|c|c|c|c|c|c|c|c|c|c|c|}
\hline \multirow{3}{*}{ province } & \multicolumn{12}{|c|}{ Declaration } & \multicolumn{13}{|c|}{ Permission } & \multirow{3}{*}{ Total } \\
\hline & \multirow{2}{*}{\multicolumn{3}{|c|}{$\frac{\text { Mountain }}{\mathrm{S} \text { S }+\mathrm{G} \text { G sum }}$}} & \multicolumn{4}{|c|}{ Washing } & \multicolumn{4}{|c|}{ Crushed } & \multirow{2}{*}{$\begin{array}{l}\text { Dec. } \\
\text { sum }\end{array}$} & \multicolumn{4}{|c|}{ Mountain } & \multicolumn{4}{|c|}{ Land } & \multicolumn{4}{|c|}{ River } & \multirow{2}{*}{$\begin{array}{l}\text { Per. } \\
\text { sum }\end{array}$} & \\
\hline & & & & $\bar{S}$ & $\mathrm{~S}+\mathrm{G}$ & G su & $\overline{s u m}$ & $\mathrm{~S}$ & $\mathrm{~S}+\mathrm{G}$ & $\mathrm{G}$ & $\overline{\text { sum }}$ & & $\bar{S}$ & $\mathrm{~S}+\mathrm{G}$ & $\mathrm{G}$ & $\overline{\text { sum }}$ & $\mathrm{S}$ & $\mathrm{S}+\mathrm{G}$ & G sur & & $\mathrm{S}$ & $\mathrm{S}+\mathrm{G}$ & $\mathrm{G}$ & $\overline{\text { sum }}$ & & \\
\hline \multicolumn{27}{|l|}{$\overline{\text { Seoul }}$} \\
\hline Incheon & & 1 & 1 & 3 & 1 & & 4 & 1 & 2 & 9 & 12 & 17 & & & & & & & & & & & & & & 17 \\
\hline Gyeonggi-do & & & & 2 & 1 & & 3 & 29 & 39 & 55 & 123 & 126 & 1 & 5 & 3 & 9 & & & & & & & & & 9 & 135 \\
\hline Gangwon-do & 1 & & 1 & & & & & 13 & 8 & 15 & 36 & 37 & 1 & 3 & 13 & 17 & 33 & 3 & 84 & 4 & & & 15 & 15 & 76 & 113 \\
\hline Chungcheongbuk-do & & & & & & & & 30 & 1 & 15 & 46 & 46 & & & 19 & 19 & 15 & & 116 & 6 & & & & & 35 & 81 \\
\hline Daejeon & & & & & & & & 1 & & & 1 & 1 & & & & & & & & & & & & & & 1 \\
\hline Sejong & & & & & & & & & 9 & 5 & 14 & 14 & & & 2 & 2 & 2 & & 2 & 2 & & & & & 4 & 18 \\
\hline Chungcheongnam-do & & & & 1 & & & 1 & 8 & 8 & 16 & 32 & 33 & 2 & 2 & 17 & 21 & 9 & & 9 & 9 & & & & & 30 & 63 \\
\hline Jeollabuk-do & 1 & & 1 & & & & & 13 & 3 & 7 & 23 & 24 & 6 & 2 & 20 & 28 & 18 & & 18 & 8 & & & & & 46 & 70 \\
\hline \multicolumn{27}{|l|}{ Gwangju } \\
\hline Jeollanam-do & & 1 & 1 & 4 & & & 4 & 1 & & 11 & 12 & 17 & 3 & & 24 & 27 & 13 & & 13 & 3 & & & & & 40 & 57 \\
\hline $\begin{array}{l}\text { Daegu } \\
\text { ne }\end{array}$ & & & & & & & & 2 & & 9 & 11 & 11 & & & & & & & & & & & & & & 11 \\
\hline Gyeongsangbuk-do & & & & & & & & 11 & 7 & 14 & 32 & 32 & 1 & 8 & 24 & 33 & 68 & 14 & 82 & 2 & 1 & 1 & & 2 & 117 & 149 \\
\hline Busan & & & & 2 & & & 2 & 4 & 4 & 8 & 16 & 18 & & & & & & & & & & & & & & 18 \\
\hline Ulsan & & & & 1 & & & 1 & 1 & & 12 & 13 & 14 & & & 5 & 5 & & & & & & & & & 5 & 19 \\
\hline Gyeongsangnam-do & & & & 17 & & & 17 & 2 & 6 & 31 & 39 & 56 & & 11 & 21 & 32 & 2 & & 2 & 2 & 2 & & & 2 & 36 & 92 \\
\hline Jeju-do & & & & 3 & & 25 & 5 & & & 7 & 7 & 12 & & & 11 & 11 & & & $5 \quad 5$ & 5 & & & & & 16 & 28 \\
\hline Total & 11 & 2 & 4 & 33 & 2 & 23 & 37 & 116 & 87 & 214 & 417 & 458 & 14 & 31 & 159 & 204 & 160 & 17 & 1419 & 91 & 3 & 1 & 15 & 19 & 414 & 872 \\
\hline
\end{tabular}

Dec. : Declaration, Per. : Permission, S : sand, G: gravel 
Table 2. Aggregate production in Korea in 2019, by provinces and size of operation

\begin{tabular}{|c|c|c|c|c|c|c|c|c|c|c|c|c|}
\hline \multirow{2}{*}{$\begin{array}{c}\text { size range } \\
\text { (thousand } \mathrm{m}^{3} \text { ) }\end{array}$} & \multicolumn{2}{|c|}{ Gyeonggi-do } & \multicolumn{2}{|c|}{ Incheon } & \multicolumn{2}{|c|}{ Gangwon-do } & \multicolumn{2}{|c|}{$\begin{array}{l}\text { Chungcheongbuk- } \\
\text { do }\end{array}$} & \multicolumn{2}{|c|}{$\begin{array}{c}\text { Chungcheongnam- } \\
\text { do }\end{array}$} & \multicolumn{2}{|c|}{ Daejeon } \\
\hline & $\begin{array}{l}\text { number of } \\
\text { operations }\end{array}$ & puantities & $\begin{array}{l}\text { number of } \\
\text { operations }\end{array}$ & $\overline{\text { uantities }}$ & $\begin{array}{c}\text { number of } \\
\text { operations }\end{array}$ & $\overline{\text { quantities }}$ & $\begin{array}{l}\text { number of } \\
\text { operations }\end{array}$ & $\overline{\text { uantities }}$ & $\begin{array}{l}\text { number of } \\
\text { operations }\end{array}$ & $\overline{\text { dantities }}$ & $\begin{array}{c}\text { number of } \\
\text { operations }\end{array}$ & quantities \\
\hline less than 10 & 3 & 5 & 0 & 0 & 43 & 180 & 6 & 35 & 6 & 31 & 0 & 0 \\
\hline $10 \sim<20$ & 1 & 19 & 0 & 0 & 15 & 208 & 10 & 140 & 7 & 98 & 0 & 0 \\
\hline $20 \sim<40$ & 12 & 326 & 2 & 65 & 17 & 489 & 9 & 249 & 9 & 220 & 1 & 29 \\
\hline $40 \sim<60$ & 11 & 525 & 1 & 49 & 8 & 384 & 9 & 439 & 3 & 138 & 0 & 0 \\
\hline $60 \sim<80$ & 6 & 406 & 0 & 0 & 10 & 679 & 7 & 466 & 8 & 561 & 0 & 0 \\
\hline $80 \sim<100$ & 10 & 866 & 1 & 89 & 2 & 189 & 6 & 535 & 2 & 175 & 0 & 0 \\
\hline $100 \sim<200$ & 24 & 3,472 & 4 & 628 & 4 & 602 & 16 & 2,454 & 16 & 2,321 & 0 & 0 \\
\hline $200 \sim<300$ & 21 & 5,117 & 2 & 528 & 5 & 1,129 & 8 & 2,014 & 6 & 1,470 & 0 & 0 \\
\hline $300 \sim<400$ & 10 & 3,510 & 2 & 696 & 4 & 1,434 & 4 & 1,418 & 2 & 669 & 0 & 0 \\
\hline $400 \sim<500$ & 9 & 4,004 & 1 & 496 & 0 & 0 & 2 & 823 & 1 & 469 & 0 & 0 \\
\hline $500 \sim<600$ & 8 & 4,268 & 2 & 1,123 & 3 & 1,638 & 1 & 571 & 1 & 524 & 0 & 0 \\
\hline $600 \sim<700$ & 5 & 3,183 & 2 & 1,253 & 0 & 0 & 1 & 696 & 0 & 0 & 0 & 0 \\
\hline $700 \sim<800$ & 1 & 765 & 0 & 0 & 0 & 0 & 0 & 0 & 0 & 0 & 0 & 0 \\
\hline $800 \sim<900$ & 5 & 4,240 & 0 & 0 & 0 & 0 & 0 & 0 & 0 & 0 & 0 & 0 \\
\hline $900 \sim<1,000$ & 1 & 950 & 0 & 0 & 1 & 996 & 2 & 1,919 & 0 & 0 & 0 & 0 \\
\hline $1,000 \sim<1,500$ & 8 & 10,014 & 0 & 0 & 1 & 1,149 & 0 & 0 & 2 & 2,385 & 0 & 0 \\
\hline $1,500 \sim<2,000$ & 0 & 0 & 0 & 0 & 0 & 0 & 0 & 0 & 0 & 0 & 0 & 0 \\
\hline 2,000 and more & 0 & 0 & 0 & 0 & 0 & 0 & 0 & 0 & 0 & 0 & 0 & 0 \\
\hline total & 135 & 41,669 & 17 & 4,927 & 113 & 9,075 & 81 & 11,759 & 63 & 9,061 & 1 & 29 \\
\hline
\end{tabular}

Table 2. Continued

\begin{tabular}{|c|c|c|c|c|c|c|c|c|c|c|c|c|}
\hline \multirow{2}{*}{$\begin{array}{c}\text { size range } \\
\text { (thousand } \mathrm{m}^{3} \text { ) }\end{array}$} & \multicolumn{2}{|c|}{ Sejong } & \multicolumn{2}{|c|}{ Jeollabuk-do } & \multicolumn{2}{|c|}{ Jeollanam-do } & \multicolumn{2}{|c|}{ Gyeongsangbuk-do } & \multicolumn{2}{|c|}{ Daegu } & \multicolumn{2}{|c|}{ Gyeongsangnam-do } \\
\hline & $\begin{array}{l}\text { number of } \\
\text { operations }\end{array}$ & quantities & $\begin{array}{c}\text { number of } \\
\text { operations }\end{array}$ & quantities & $\begin{array}{l}\text { number of } \\
\text { operations }\end{array}$ & quantities & $\begin{array}{c}\text { number of } \\
\text { operations }\end{array}$ & $\overline{\text { lantities }}$ & $\begin{array}{c}\text { number of } \\
\text { operations }\end{array}$ & $\overline{\text { ntities }}$ & $\begin{array}{l}\text { number of } \\
\text { operations }\end{array}$ & quantities \\
\hline less than 10 & 0 & 0 & 10 & 54 & 8 & 34 & 33 & 153 & 1 & 9 & 15 & 62 \\
\hline $10 \sim<20$ & 1 & 16 & 9 & 136 & 6 & 75 & 30 & 434 & 3 & 40 & 7 & 93 \\
\hline $20 \sim<40$ & 3 & 85 & 10 & 296 & 7 & 193 & 33 & 884 & 1 & 35 & 6 & 185 \\
\hline $40 \sim<60$ & 3 & 94 & 9 & 423 & 6 & 299 & 15 & 750 & 3 & 161 & 8 & 401 \\
\hline $60 \sim<80$ & 1 & 64 & 4 & 268 & 3 & 200 & 9 & 626 & 0 & 0 & 8 & 578 \\
\hline $80 \sim<100$ & 1 & 89 & 6 & 509 & 4 & 348 & 4 & 359 & 1 & 96 & 7 & 635 \\
\hline $100 \sim<200$ & 8 & 1096 & 13 & 1,934 & 8 & 1,112 & 15 & 1,966 & 2 & 226 & 20 & 2,865 \\
\hline $200 \sim<300$ & 1 & 234 & 2 & 434 & 8 & 1,943 & 4 & 1,006 & 0 & 0 & 6 & 1,475 \\
\hline $300 \sim<400$ & 1 & 393 & 4 & 1,340 & 3 & 1,065 & 2 & 651 & 0 & 0 & 7 & 2,455 \\
\hline $400 \sim<500$ & 0 & 0 & 1 & 415 & 0 & 0 & 2 & 910 & 0 & 0 & 2 & 873 \\
\hline $500 \sim<600$ & 0 & 0 & 0 & 0 & 0 & 0 & 1 & 583 & 0 & 0 & 1 & 552 \\
\hline $600 \sim<700$ & 0 & 0 & 1 & 683 & 1 & 647 & 0 & 0 & 0 & 0 & 3 & 1,983 \\
\hline $700 \sim<800$ & 0 & 0 & 0 & 0 & 0 & 0 & 1 & 745 & 0 & 0 & 0 & 0 \\
\hline $800 \sim<900$ & 0 & 0 & 0 & 0 & 3 & 2,586 & 0 & 0 & 0 & 0 & 0 & 0 \\
\hline $900 \sim<1,000$ & 0 & 0 & 0 & 0 & 0 & 0 & 0 & 0 & 0 & 0 & 0 & 0 \\
\hline $1,000 \sim<1,500$ & 0 & 0 & 1 & 1,107 & 0 & 0 & 0 & 0 & 0 & 0 & 2 & 2,254 \\
\hline $1,500 \sim<2,000$ & 0 & 0 & 0 & 0 & 0 & 0 & 0 & 0 & 0 & 0 & 0 & 0 \\
\hline 2,000 and more & 0 & 0 & 0 & 0 & 0 & 0 & 0 & 0 & 0 & 0 & 0 & 0 \\
\hline total & 19 & 2,071 & 70 & 7,599 & 57 & 8,502 & 149 & 9,067 & 11 & 568 & 92 & 14,410 \\
\hline
\end{tabular}


Table 2. Continued

\begin{tabular}{|c|c|c|c|c|c|c|}
\hline \multirow{2}{*}{$\begin{array}{c}\text { size range } \\
\text { (thousand } \mathrm{m}^{3} \text { ) }\end{array}$} & \multicolumn{2}{|l|}{ Busan } & \multicolumn{2}{|l|}{ Ulsan } & \multicolumn{2}{|l|}{ Jeju-do } \\
\hline & number of operations & quantities & number of operations & quantities & number of operations & quantities \\
\hline less than 10 & 1 & 4 & 0 & 0 & 3 & $\overline{14}$ \\
\hline $10 \sim 20$ & 1 & 16 & 1 & 15 & 6 & 88 \\
\hline $20 \sim<40$ & 0 & 0 & 3 & 83 & 5 & 156 \\
\hline $40 \sim<60$ & 1 & 47 & 0 & 0 & 4 & 177 \\
\hline $60 \sim<80$ & 3 & 200 & 3 & 212 & 5 & 349 \\
\hline $80 \sim<100$ & 1 & 82 & 1 & 81 & 1 & 99 \\
\hline $100 \sim<200$ & 6 & 1038 & 5 & 680 & 4 & 538 \\
\hline $200 \sim<300$ & 3 & 832 & 2 & 477 & 0 & 0 \\
\hline $300 \sim<400$ & 1 & 380 & 0 & 0 & 0 & 0 \\
\hline $400 \sim<500$ & 1 & 441 & 1 & 416 & 0 & 0 \\
\hline $500 \sim<600$ & 0 & 0 & 0 & 0 & 0 & 0 \\
\hline $600 \sim<700$ & 0 & 0 & 0 & 0 & 0 & 0 \\
\hline $700 \sim<800$ & 0 & 0 & 0 & 0 & 0 & 0 \\
\hline $800 \sim<900$ & 0 & 0 & 0 & 0 & 0 & 0 \\
\hline $900 \sim<1,000$ & 0 & 0 & 0 & 0 & 0 & 0 \\
\hline $1,000 \sim<1,500$ & 0 & 0 & 1 & 1,235 & 0 & 0 \\
\hline $1,500 \sim<2,000$ & 0 & 0 & 1 & 1,676 & 0 & 0 \\
\hline 2,000 and more & 0 & 0 & 1 & 3,305 & 0 & 0 \\
\hline total & 18 & 3,040 & 19 & 8,179 & 28 & $\overline{1,421}$ \\
\hline
\end{tabular}

고 모래와 자갈 모두 채취한 채취장은 40 개소이다. 경기 도에서 10 개소 이상의 채취장에서 골재를 개발하는 지역 은 5 개 시군구이며, 5 10개의 채취장은 4 개 시군구, 그 밖의 시군구에서는 5 개 이하의 채취장이 운영되고 있다. 채취장들 중 100 만 $\mathrm{m}^{3}$ 이상의 골재개발은 8 개 채취장에 서 이루어졌으며, 50 만 100 만 $\mathrm{m}^{3}$ 미만의 골재채취는 20 개 채취장에서, 10 만 50 만 $\mathrm{m}^{3}$ 미만의 골재채취는 64 개 채취장에서, 4 만 10 만 $\mathrm{m}^{3}$ 미만은 27 개 채취장에서, 1 만 $\sim 4$ 만 $\mathrm{m}^{3}$ 미만은 13 개 채취장에서 1 만 $\mathrm{m}^{3}$ 미만의 채취장 은 3 개소이다(Table 2). 따라서 경기도에서의 골재채취는 대부분 10 만 $\mathrm{m}^{3}$ 이상 개발이 우세한데 특히, 50 만 $\mathrm{m}^{3}$ 이 상을 개발하는 채취장에서의 골재 생산량은 경기도 골재 생산량의 약 $50 \%$ 로 타 시도에 비해서는 비교적 골재채 취장의 규모가 큰 편이다. 경기도에서의 허가골재 채취 장은 9 개소인데 허가기간이 15 년 이상인 채취장은 1 개소 이며, 10년 15년인 채취장은 없으며, 5 10년인 채취장은 7 개소, 1 년 5 년인 채취장은 1 개소이며, 허가기간이 1 년 이하인 채취장은 없다. 2020 년부터 허가기간이 남아 골 재채취가 가능한 채취장은 9 개소이며, 이 중 5년 10년 남은 채취장은 1 개소, 1 년 5 년인 채취장은 5 개, 1 년 이 하인 채취장은 3 개소이다.

강원권 : 강원도에서 2019년에 골재개발이 행해진 채취
장은 113 개이다(Table 1). 이 중 골재허가에 의한 채취장 은 76 개소이며, 신고에 의한 채취장은 37 개소이다. 허가 에 의한 채취장 중 산림골재는 17 개소, 육상골재 44 개소, 하천골재 15 개소이다. 또한 모래만 채취한 채취장은 49 개소, 자갈만 채취한 채취장은 51 개소, 그리고 모래와 자 갈 모두 채취한 채취장은 13 개소이다(Table 1). 강원도에 서 10 개소 이상의 채취장에서 골재를 개발하는 지역은 4 개 시군구이며, 5 10개의 채취장은 4 개 시군구, 그 밖의 시군구에서는 5 개 이하의 채취장이 운영되고 있다. 채취 장들 중 100 만 $\mathrm{m}^{3}$ 이상의 골재개발은 1 개 채취장에서 이 루어졌으며, 50 만 100 만 $\mathrm{m}^{3}$ 미만의 골재채취는 4 개 채 취장에서, 10 만 50 만 $\mathrm{m}^{3}$ 미만의 골재채취는 13 개 채취장 에서, 4 만 10 만 $\mathrm{m}^{3}$ 미만은 20 개 채취장에서, 1 만 4 만 $\mathrm{m}^{3}$ 미만은 32 개 채취장에서 1 만 $\mathrm{m}^{3}$ 미만의 채취장은 43 개 소이다(Table 2). 따라서 강원도에서의 골재채취는 대부 분 4 만 $\mathrm{m}^{3}$ 이하의 소규모 개발이 우세한데 이는 강원도 에서는 소규모의 육상골재의 개발이 활발하기 때문이다. 강원도에서 허가골재 채취장은 76 개소인데 허가기간이 20년 이상인 채취장은 없으며, 15년 20년인 채취장은 5 개소이며, 10 년 15 년인 채취장은 5 개소, 5 10년인 채취 장은 6 개소, 1 년 5 년인 채취장은 32 개소이며, 허가기간 이 1 년 이하인 채취장은 28 개소이다. 2020 년부터 허가기 
간이 남아 골재채취가 가능한 채취장은 49개소이며, 이 중 5 년 10 년 남은 채취장은 5 개소, 1 년 5 년인 채취장은 12 개, 1 년 이하인 채취장은 32 개소이다.

충북권 : 충청북도에서 2019년에 골재개발이 행해진 채 취장은 81개이다(Table 1). 이 중 골재허가에 의한 채취 장은 35 개소이며, 신고에 의한 채취장은 46 개소이다. 허 가에 의한 채취장은 육상골재와 산림골재 채취장이다. 또 한 81 개 채취장 중에서 모래만 채취한 채취장은 45 개소, 자갈만 채취한 채취장은 35 개소, 그리고 모래와 자갈 모 두 채취한 채취장은 1 개소이다(Table 1). 충청북도에서 10 개소 이상의 채취장에서 골재를 개발하는 지역은 2 개 시 군구이며, $5 \sim 10$ 개의 채취장은 3 개 시군구, 그 밖의 시군 구에서는 5 개 이하의 채취장이 운영되고 있다. 채취장들 중 100 만 $\mathrm{m}^{3}$ 이상의 골재개발은 없으며, 50 만 100 만 $\mathrm{m}^{3}$ 미만의 골재채취는 4 개 채취장에서, 10 만 50 만 $\mathrm{m}^{3}$ 미만의 골재채취는 30 개 채취장에서, 4 만 10 만 $\mathrm{m}^{3}$ 미만은 22 개 채취장에서, 1 만 4 만 $\mathrm{m}^{3}$ 미만은 19 개 채취장에서 1 만 $\mathrm{m}^{3}$ 미만의 채취장은 6 개소이다(Table 2). 10 만 $\mathrm{m}^{3}$ 이상의 채 취장이 34 개소로 충북 전체 채취장의 약 $42 \%$ 를 점유하 는데 비해 골재 생산량은 충북 총생산량의 약 $84 \%$ 를 점 한다. 충청북도에서 허가골재 채취장은 35 개소인데 허가 기간이 20 년 이상인 채취장은 3 개소, 15 년 20 년인 채취 장은 1 개소이며, 10 년 15 년인 채취장은 4 개소, $5 \sim 10$ 년인 채취장은 8 개소, 1 년 5 년인 채취장은 9 개소이며, 허가기 간이 1 년 이하인 채취장은 10 개소이다. 2020 년부터 허가 기간이 남아 골재채취가 가능한 채취장은 27 개소이며, 이 중 5년 10년 남은 채취장은 2 개소, 1 년 5 년인 채취장은 10 개, 1 년 이하인 채취장은 15 개소이다.

대전, 세종, 충남권 : 충청남도에서 2019년에 골재개발 이 행해진 채취장은 약 63 개이다(Table 1). 이 중 골재허 가에 의한 채취장은 30 개소이며, 신고에 의한 채취장은 33 개소이다. 허가에 의한 채취장은 대부분 산림골재 채 취장이며, 육상골재 채취장은 극소수이다. 또한 63 개 채 취장 중에서 모래만 채취한 채취장은 20 개소, 자갈만 채 취한 채취장은 33 개소, 그리고 모래와 자갈 모두 채취한 채취장은 10 개소이다(Table 1). 충청남도에서 10 개소 이 상의 채취장에서 골재를 개발하는 지역은 1 개 시군구이 며, $5 \sim 10$ 개의 채취장은 3 개 시군구, 그 밖의 시군구에서 는 5 개 이하의 채취장이 운영되고 있다. 채취장들 중 100 만 $\mathrm{m}^{3}$ 이상의 골재를 개발하는 곳은 2 개소이며, 50 만 100 만 $\mathrm{m}^{3}$ 미만의 골재채취는 1 개 채취장에서, 10 만 50 만 $\mathrm{m}^{3}$ 미만의 골재채취는 25 개 채취장에서, 4 만 10 만 $\mathrm{m}^{3}$ 미만 은 13 개 채취장에서, 1 만 4 만 $\mathrm{m}^{3}$ 미만은 16 개 채취장에 서 1 만 $\mathrm{m}^{3}$ 미만의 채취장은 6 개소이다(Table 2). 10 만 $\mathrm{m}^{3}$ 이상의 채취장이 28 개소로 충청남도 전체 채취장의 약
$44 \%$ 를 점유하는데 비해 골재 생산량은 충청남도 총생산 량의 약 $87 \%$ 를 점한다. 충청남도에서 허가골재 채취장 은 30 개소인데 허가기간이 20 년 이상인 채취장은 3 개소 이며, 15 년 20 년인 채취장은 없으며, 10 년 15 년인 채취 장은 3 개소, $5 \sim 10$ 년인 채취장은 11 개소, 1 년 5 년인 채취 장은 6 개소이며, 허가기간이 1 년 이하인 채취장은 6 개소 이다. 2020년부터 허가기간이 남아 골재채취가 가능한 채 취장은 22 개소이며, 이 중 5 년 10 년 남은 채취장은 6 개 소, 1 년 5 년인 채취장은 10 개, 1 년 이하인 채취장은 6 개 소이다.

세종특별자치시에서 2019년에 골재개발이 행해진 채취 장은 약 18 개소이다(Table 1). 이 중 골재허가에 의한 채 취장은 4 개소이며, 신고에 의한 채취장은 14 개소이다. 허 가에 의한 채취장은 산림골재와 육상골재 채취장이다. 또 한 18 개 채취장 중에서 모래만 채취한 채취장은 2 개소, 자갈만 채취한 채취장은 7 개소, 그리고 모래와 자갈 모두 채취한 채취장은 9 개소이다(Table 1). 채취장들 중 50 만 $\mathrm{m}^{3}$ 이상의 골재를 개발 채취장은 없으며, 10 만 50 만 $\mathrm{m}^{3}$ 미 만의 골재채취는 10 개 채취장에서, 4 만 10 만 $\mathrm{m}^{3}$ 미만은 5 개 채취장에서, 1 만 4 만 $\mathrm{m}^{3}$ 미만은 4 개 채취장에서 1 만 $\mathrm{m}^{3}$ 미만의 채취장은 없다(Table 2). 세종특별자치시는 대부 분의 골재는 $10 \sim 50$ 만 $\mathrm{m}^{3}$ 규모의 채취장에서 채취된다. 세종특별자치시에서 허가골재 채취장은 4 개소인데 허가 기간이 명시된 채취장들 중에서 허가기간이 1년 5년인 채취장은 1 개소이며, 허가기간이 1 년 이하인 채취장은 2 개소이다. 2020년부터 허가기간이 남아 골재채취가 가능 한 채취장은 3 개소이며, 모두 1 년 이하인 채취장이다.

전북권 : 2019년에 전라북도에서 골재개발을 한 채취 장은 70 개소이다(Table 1). 이 중 골재허가에 의한 채취 장은 46 개소이며, 신고에 의한 채취장은 24 개소로 허가 에 의한 골재개발이 압도적으로 많은 편이다. 허가에 의 한 채취장은 산림골재 28 개소, 육상골재 18 개소이다. 또 한 모래만 채취한 채취장은 37 개소, 자갈만 채취한 채취 장은 27 개소, 그리고 모래와 자갈 모두 채취한 채취장은 6 개소이다(Table 1). 전라북도에서 10 개소 이상의 채취장 에서 골재를 개발하는 지역은 4 개 시군구이며, 나머지 시 군구에서는 5 개 이하의 채취장이 운영되고 있다. 채취장 들 중 100 만 $\mathrm{m}^{3}$ 이상의 골재를 개발한 채취장은 1 개소 이며, 50 만 100 만 $\mathrm{m}^{3}$ 미만의 골재채취는 1 개 채취장에 서, 10 만 50 만 $\mathrm{m}^{3}$ 미만의 골재채취는 20 개 채취장에서, 4 만 10 만 $\mathrm{m}^{3}$ 미만은 19 개 채취장에서, 1 만 4 만 $\mathrm{m}^{3}$ 미만 은 19 개 채취장에서, 1 만 $\mathrm{m}^{3}$ 미만의 채취장은 10 개소이 다(Table 2). 10 만 $\mathrm{m}^{3}$ 이상의 채취장이 22 개소로 전라북 도 전체 채취장의 약 $30 \%$ 를 점유하는데 비해 골재 생산 량은 전라북도 총생산량의 약 $78 \%$ 를 점한다. 전라북도 
에서의 허가골재 채취장은 46개소인데, 허가기간이 명시 된 채취장들 중에서 허가기간이 20년 이상인 채취장은 1 개소이며, 15 년 20 년인 채취장은 2 개소, 10 년 15 년인 채 취장은 3 개소, 5 10년인 채취장은 14 개소, 1 년 5 년인 채 취장은 21 개소이며, 허가기간이 1 년 이하인 채취장은 3 개소이다. 2020년부터 허가기간이 남아 골재채취가 가능 한 채취장은 31 개소이며, 이 중 5년 10년 남은 채취장은 5 개소, 1 년 5 년인 채취장은 14 개, 1 년 이하인 채취장은 12 개소이다.

광주, 전남권 : 2019년에 전라남도에서 골재개발을 한 채취장은 57 개소이다(Table 1). 이 중 골재허가에 의한 채 취장은 40 개소이며, 신고에 의한 채취장은 17 개소로 허 가에 의한 골재개발이 압도적으로 많은 편이다. 허가에 의한 채취장은 산림골재 27 개소, 육상골재 13 개소이다. 또한 모래만 채취한 채취장은 21 개소, 자갈만 채취한 채 취장은 36개소, 그리고 모래와 자갈 모두 채취한 채취장 은 없다(Table 1). 전라남도에서 6개소의 채취장에서 골 재를 개발하는 지역은 3 개 시군구이며, 나머지 시군구에 서는 5 개 이하의 채취장이 운영되고 있다. 채취장들 중 100 만 $\mathrm{m}^{3}$ 이상의 골재를 개발한 채취장은 없으며, 50 만 $\sim 100$ 만 $\mathrm{m}^{3}$ 미만의 골재채취는 4 개 채취장에서, 10 만 50 만 $\mathrm{m}^{3}$ 미만의 골재채취는 19 개 채취장에서, 4 만 10 만 $\mathrm{m}^{3}$ 미만은 13 개 채취장에서, 1 만 4 만 $\mathrm{m}^{3}$ 미만은 13 개 채취 장에서, 1 만 $\mathrm{m}^{3}$ 미만의 채취장은 8 개소이다(Table 2). 10 만 $\mathrm{m}^{3}$ 이상의 채취장이 23 개소로 전라남도 전체 채취장 의 약 $40 \%$ 를 점유하는데 비해 골재 생산량은 전라북도 총생산량의 약 $87 \%$ 를 점한다. 전라남도에서의 허가골재 채취장은 40 개소인데, 허가기간이 명시된 채취장들 중에 서 허가기간이 20 년 이상인 채취장은 1 개소이며, 15 년 20 년인 채취장은 2 개소, 10 년 15 년인 채취장은 3 개소, $5 \sim 10$ 년인 채취장은 9개소, 1 년 5년인 채취장은 24 개소이 며, 허가기간이 1년 이하인 채취장은 1 개소이다. 2020 년 부터 허가기간이 남아 골재채취가 가능한 채취장은 35 개 소이며, 이 중 5년 10년 남은 채취장은 6개소, 1년 5년 인 채취장은 12 개, 1 년 이하인 채취장은 17 개소이다.

대구, 경북권 : 2019년에 경상북도에서 골재개발을 한 채취장은 149 개소이다(Table 1). 이 중 골재허가에 의한 채취장은 117 개소이며, 신고에 의한 채취장은 32 개소로 허가에 의한 골재개발이 압도적으로 많은 편이다. 허가 에 의한 채취장은 육상골재 82 개소, 산림골재 33 개소, 하 천골재 2 개소이다. 또한 모래만 채취한 채취장은 81 개소, 자갈만 채취한 채취장은 38 개소, 그리고 모래와 자갈 모 두 채취한 채취장은 30 개소이다(Table 1). 경상북도에서 10 개소 이상의 채취장에서 골재를 개발하는 지역은 6 개 시군구이며, $5 \sim 10$ 개의 채취장은 5 개 시군구, 그 밖의 시
군구에서는 5 개 이하의 채취장이 운영되고 있다. 채취장 들 중 100 만 $\mathrm{m}^{3}$ 이상의 골재를 개발한 채취장은 없으며, 50 만 100 만 $\mathrm{m}^{3}$ 미만의 골재채취는 2 개 채취장에서, 10 만 50 만 $\mathrm{m}^{3}$ 미만의 골재채취는 23 개 채취장에서, 4 만 10 만 $\mathrm{m}^{3}$ 미만은 28 개 채취장에서, 1 만 4 만 $\mathrm{m}^{3}$ 미만은 63 개 채취장에서 1 만 $\mathrm{m}^{3}$ 미만의 채취장은 33 개소이다(Table 2). 10 만 $\mathrm{m}^{3}$ 이상의 채취장이 25 개소로 경상북도 전체 채취 장의 약 $17 \%$ 를 점유하는데 비해 골재 생산량은 경상북 도 총생산량의 약 $65 \%$ 를 점한다. 경상북도에서의 허가 골재 채취장은 117 개소인데 허가기간이 20 년 이상인 채 취장은 2 개소이며, 15 년 20년인 채취장은 4 개소, 10 년 $\sim 15$ 년인 채취장은 3 개소, $5 \sim 10$ 년인 채취장은 17 개소, 1 년 5 년인 채취장은 28 개소이며, 허가기간이 1 년 이하인 채취장은 63개소이다. 2020년부터 허가기간이 남아 골재 채취가 가능한 채취장은 61 개소이며, 이 중 5년 10년 남 은 채취장은 8 개소, 1 년 5 년인 채취장은 15 개, 1 년 이하 인 채취장은 38 개소이다.

2019년에 대구광역시에서 골재개발을 한 채취장은 11 개소로 모두 신고에 의한 채취장이다(Table 1). 또한 모 래만 채취한 채취장은 2 개소, 자갈만 채취한 채취장은 9 개소, 그리고 모래와 자갈 모두 채취한 채취장은 없다 (Table 1). 대구광역시에서 달서구가 5 개소의 채취장이 운 영되고 있으며, 달성군 3 개소, 북구 2 개소, 동구 1 개소의 채취장이 운영되고 있다. 채취장들 중 50 만 $\mathrm{m}^{3}$ 이상의 골재를 개발한 채취장은 없으며, 10 만 50 만 $\mathrm{m}^{3}$ 미만의 골재채취는 2 개 채취장에서, 4 만 10 만 $\mathrm{m}^{3}$ 미만은 4 개 채 취장에서, 1 만 4 만 $\mathrm{m}^{3}$ 미만은 4 개 채취장에서, 1 만 $\mathrm{m}^{3}$ 미만의 채취장은 1 개소이다(Table 2).

부산, 울산, 경남권 : 경상남도에서 2019년에 골재개발 이 행해진 채취장은 약 92개이다(Table 1). 이 중 골재허 가에 의한 채취장은 36 개소이며, 신고에 의한 채취장은 56 개소이다. 허가에 의한 채취장은 대부분 산림골재 채 취장이며, 육상골재와 하천골재 채취장은 극소수이다. 또 한 92개 채취장 중에서 모래만 채취한 채취장은 23 개소, 자갈만 채취한 채취장은 52 개소, 그리고 모래와 자갈 모 두 채취한 채취장은 27 개소이다(Table 1). 경상남도에서 10 개소 이상의 채취장에서 골재를 개발하는 지역은 2 개 시군구이며, 5 10개의 채취장은 5 개 시군구, 그 밖의 시 군구에서는 5 개 이하의 채취장이 운영되고 있다. 채취장 들 중 100 만 $\mathrm{m}^{3}$ 이상의 골재채취는 2 개소이며, 50 만 100 만 $\mathrm{m}^{3}$ 미만의 골재채취는 4 개 채취장에서, 10 만 50 만 $\mathrm{m}^{3}$ 미만의 골재채취는 35 개 채취장에서, 4 만 10 만 $\mathrm{m}^{3}$ 미만 은 23 개 채취장에서, 1 만 4 만 $\mathrm{m}^{3}$ 미만은 13 개 채취장에서 1 만 $\mathrm{m}^{3}$ 미만의 채취장은 15 개소이다(Table 2). 10 만 $\mathrm{m}^{3}$ 이상의 채취장이 41 개소로 경상남도 전체 채취장의 약 
$45 \%$ 를 점유하는데 비해 골재 생산량은 경상남도 총생산 량의 약 $86 \%$ 를 점한다. 경상남도에서 허가골재 채취장 은 36 개소인데 허가기간이 20 년 이상인 채취장은 2 개소 이며, 15 년 20 년인 채취장은 4 개소이며, 10 년 15 년인 채 취장은 3 개소, $5 \sim 10$ 년인 채취장은 18 개소, 1 년 5 년인 채 취장은 5 개소이며, 허가기간이 1 년 이하인 채취장은 3 개 소이다. 2020년부터 허가기간이 남아 골재채취가 가능한 채취장은 29 개소이며, 이 중 5년 10년 남은 채취장은 5 개소, 1 년 5 년인 채취장은 18 개, 1 년 이하인 채취장은 6 개소이다.

2019년에 부산광역시에서 골재개발을 한 채취장은 18 개소이며, 모두 신고에 의한 채취장이다(Table 1). 또한 모래만 채취한 채취장은 6 개소, 자갈만 채취한 채취장은 12 개소이며, 모래와 자갈 모두 채취한 채취장은 없다 (Table 1). 부산광역시에서 기장군이 6개 채취장이 운영되 고 있으며, 그 외에 강서구, 사하구, 사상구, 영도구에서 도 골재 채취장이 운영되고 있다. 채취장들 중 50 만 $\mathrm{m}^{3}$ 이상의 골재를 개발한 채취장은 없으며, 10 만 50 만 $\mathrm{m}^{3}$ 미만의 골재채취는 11 개 채취장에서, 4 만 10 만 $\mathrm{m}^{3}$ 미만 은 5 개 채취장에서, 1 만 4 만 $\mathrm{m}^{3}$ 미만은 1 개 채취장에서 이루어졌으며, 1 만 $\mathrm{m}^{3}$ 미만은 1 개소이다(Table 2). 부산 광역시에서는 10 만 50 만 $\mathrm{m}^{3}$ 이상의 골재를 개발한 채취 장은 가장 많으며, 부산광역시 골재 채취량은 약 $89 \%$ 를 차지한다.

2019년에 울산광역시에서 골재개발을 한 채취장은 19 개소이다(Table 1). 이 중 골재허가에 의한 채취장은 4 개 소이며, 신고에 의한 채취장은 15 개소이다. 허가에 의한 채취장은 모두 산림골재이다. 또한 모래만 채취한 채취 장은 2 개소, 자갈만 채취한 채취장은 17 개소이며, 모래와 자갈 모두 채취한 채취장은 없다(Table 1). 울산광역시에 서 울주군이 가장 많은 17 개 채취장이 운영되고 있다. 채 취장들 중 100 만 $\mathrm{m}^{3}$ 이상의 골재를 개발한 채취장은 3 개소, 50 만 100 만 $\mathrm{m}^{3}$ 미만의 채취장은 없으며, 10 만 50 만 $\mathrm{m}^{3}$ 미만의 골재채취는 8 개 채취장에서, 4 만 10 만 $\mathrm{m}^{3}$ 미만은 4 개 채취장에서, 1 만 4 만 $\mathrm{m}^{3}$ 미만은 4 개 채취장 에서 이루어졌으며, 1 만 $\mathrm{m}^{3}$ 미만의 채취장은 없다(Table 2). 울산광역시에서 100 만 $\mathrm{m}^{3}$ 이상의 골재를 개발한 채취장 은 3 개소이지만 울산광역시 전체 채취량의 약 $76 \%$ 를 차 지한다. 울산광역시에서의 허가골재 채취장은 4 개소인데, 허가기간이 명시된 채취장들 중에서 허가기간이 5 년 10 년인 채취장은 4 개소이다. 2020년부터 허가기간이 남아 골재채취가 가능한 채취장 역시 4 개소이며, 모두 1년 이 하인 채취장이다.

제주권 : 2019년에 제주도에서 골재개발을 한 채취장 은 28개소이다(Table 1). 이 중 골재허가에 의한 채취장
은 16 개소이며, 신고에 의한 채취장은 12 개소이다. 허가 에 의한 채취장은 산림골재 11 개소, 육상골재 5 개소이다. 또한 모래만 채취한 채취장은 3 개소, 자갈만 채취한 채 취장은 25 개소, 그리고 모래와 자갈 모두 채취한 채취장 은 없다(Table 1). 제주도에서 제주시는 19개 채취장, 서 귀포시는 9 개 채취장에서 골재를 개발하고 있다. 채취장 들 중 50 만 $\mathrm{m}^{3}$ 이상의 골재를 개발한 채취장은 없으며, 10 만 50 만 $\mathrm{m}^{3}$ 미만의 골재채취는 4 개 채취장에서, 4 만 $\sim 10$ 만 $\mathrm{m}^{3}$ 미만은 10 개 채취장에서, 1 만 4 만 $\mathrm{m}^{3}$ 미만은 11 개 채취장에서, 1 만 $\mathrm{m}^{3}$ 미만의 채취장은 3 개소이다 (Table 2). 제주도에서는 다른 시도에 비해 상대적으로 소 규모의 채취장이 운영되고 있다. 제주도에서의 허가골재 채취장은 16 개소인데, 허가기간이 명시된 채취장들 중에 서 허가기간이 20 년인 채취장은 없으며, 15 년 20년인 채 취장은 1 개소, 10 년 15 년인 채취장은 1 개소, 5 년 10 년인 채취장은 4 개소, 1 년 5 년인 채취장은 10 개소이다. 2020 년부터 허가기간이 남아 골재채취가 가능한 채취장은 16 개소이며, 이 중 1 년 5 년인 채취장은 8 개, 1 년 이하인 채 취장은 8 개소이다.

\section{4. 토 의}

2019년에 채취실적이 있는 채취장 중에서 허가에 의한 채취장은 약 $47 \%$, 신고에 의한 채취장은 약 $53 \%$ 로 허가 채취보다는 신고채취의 비율이 약간 높은 편이다(Fig. 1(a)). 허가에 의한 채취장에서 산림골재 채취장은 204개소(평 균 27 만 $\mathrm{m}^{3}$ /채취장), 육상골재 채취장은 191 개소(평균 2 만 3 천 $\mathrm{m}^{3}$ /채취장), 하천골재 채취장은 19 개소(평균 5 만 3 천 $\mathrm{m}^{3}$ /채취장)이다(Fig. 1(b)). 산림골재 채취장이 다른 골 재 채취장에 비해 채취효율이 월등히 높다. 신고에 의한 채취장은 458 개(평균 5 만 3 천 $\mathrm{m}^{3} /$ 채취장)로 허가에 의한 채취장보다 다소 많다. 이 중 선별파쇄 채취장이 417개(평 균 16 만 $\mathrm{m}^{3}$ /채취장)소로 압도적이며, 선별세척 채취장은 37 개소(평균 6 만 $\mathrm{m}^{3}$ /채취장), 산림신고 채취장은 4 개소(평 균 2만4천 $\mathrm{m}^{3}$ /채취장)이다(Fig. 1(b)).

모래만 채취한 채취장은 328 개소(37.6\%), 자갈만 채취 한 채취장은 410 개소(47.0\%), 모래와 자갈 모두 채취한 채취장은 134 개소(15.4\%)이다(Fig. 1(c)). 골재허가를 받 고 골재를 채취하는 채취장에서 모래만 채취한 채취장은 177 개소, 자갈만 채취한 채취장은 188 개소, 모래와 자갈 을 모두 채취한 채취장은 49 개소이다. 신고에 의해 골재 를 채취하는 채취장에서 모래만 채취한 채취장은 151 개 소, 자갈만 채취한 채취장은 222 개소, 모래와 자갈을 모 두 채취한 채취장은 85 개소이다. 따라서 골재 채취장에 서는 자갈 또는 모래 중 한 품목만 주로 채취하는 것이 

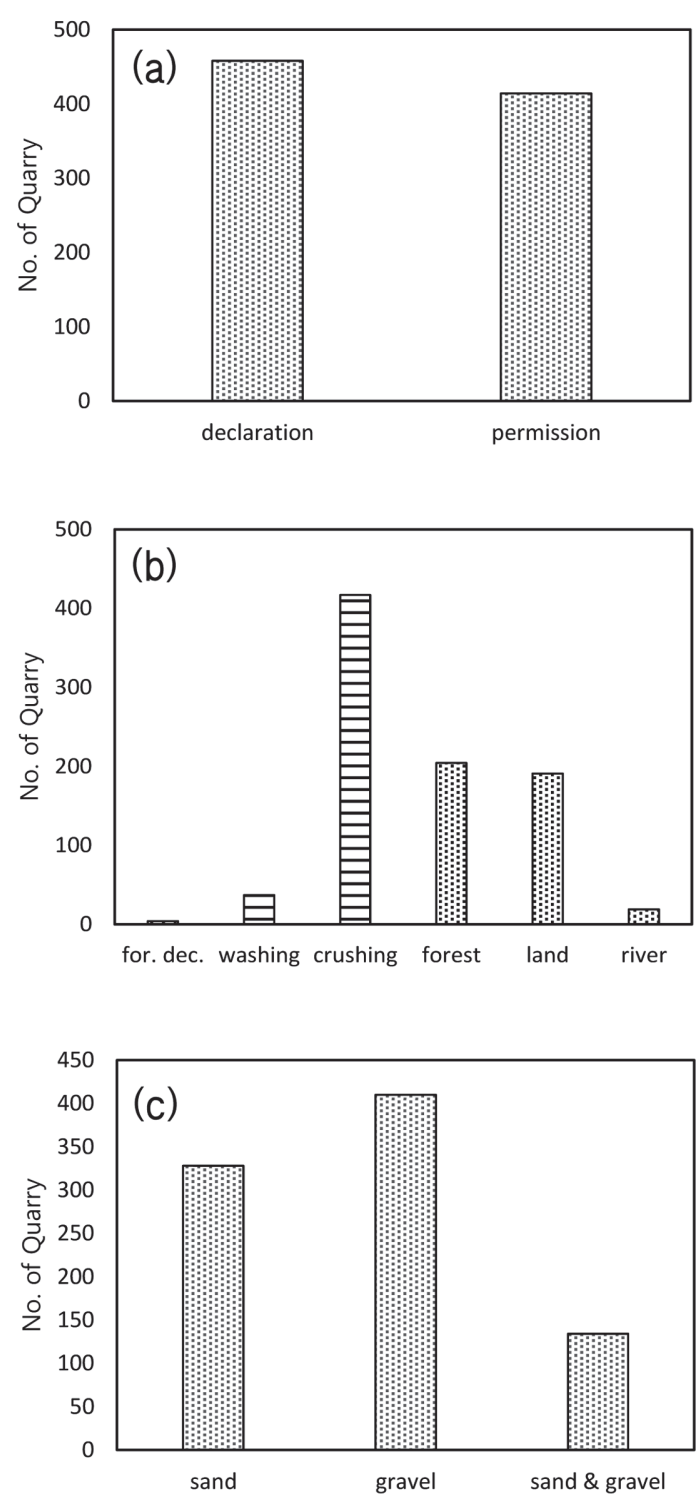

Fig. 1. Classification of the operations of aggregate in Korea, aggregate source (for.dec. : forest declaration), (c) numbers of

일반적인 패턴이다.

골재원별로 보면 선별파쇄장이 417개소(47.5\%)로 2019 년에 골재를 채취한 골재장의 거의 절반을 차지하며, 산 림골재 채취장은 204개소, 육상골재 채취장은 191개소, 선별세척 채취장은 37 개소, 하천골재 채취장은 19 개소의 순으로 채취장이 감소한다(Table 1 and Fig. 2). 이는 골 재를 채취할 수 있는 골재원은 다양하지만 점차 골재원 이 선별파쇄와 산림골재로 편중되는 경향을 보이고 있음 을 알 수 있다. 산림골재 채취장은 경상남도, 경상북도, 전라북도, 전라남도의 순이며, 모두 20 개소 이상의 채취 장을 보유하고 있다. 남원시가 산림골재 채취장이 가장 많으며, 채취장을 5 개 이상 보유한 시군구는 13 개 시군

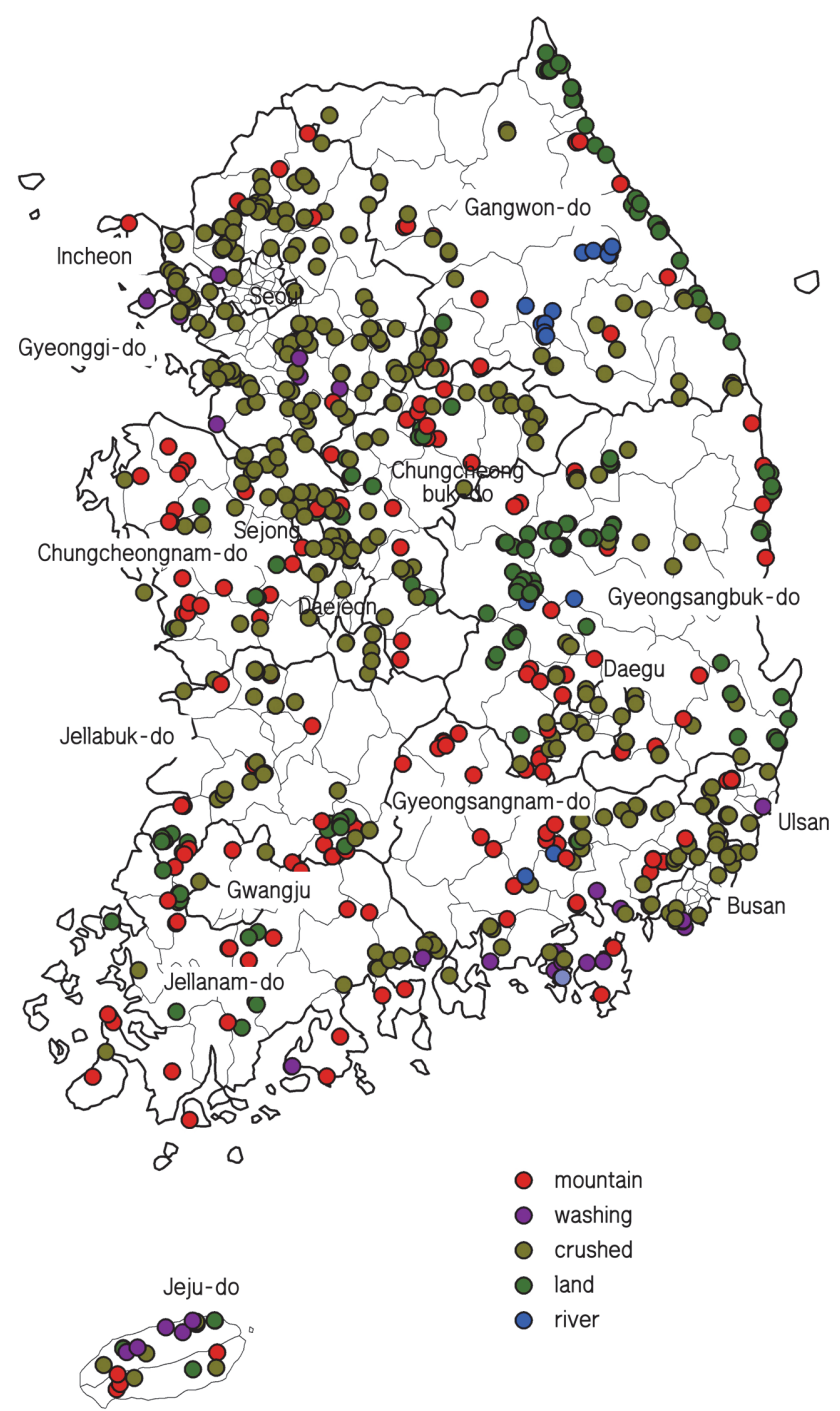

Fig. 2. The distribution map of operation sites by aggregate sources.

구이며 이들 시군구에서는 국내 산림골재 채취량의 약 $40 \%$ 를 개발하고 있다. 육상골재는 주로 논의 하부에 분 포하는 제 4 기 퇴적층을 대상으로 골재를 개발한다. 따라 서 육상골재의 개발이 활발한 지역은 충적층 평야가 넓 은 지역임을 추정할 수 있다. 육상골재 채취장은 강원도 고성군이 가장 많으며, 6 개 시군구에서 10 개소 이상의 채 취장이 운영되었다. 육상골재의 허가채취가간이 1년 이 하인 채취장이 약 $50 \%, 1$ 2년이 $34 \%$ 로 육상골재의 채 취장은 대부분 2 년 이내에서 운영되고 있음을 알 수 있 다. 이는 육상골재는 주로 논에서 골재개발을 하게 되므 로, 농업활동에 가급적 지장을 주지 않아야 하므로 단기 간에 집중적으로 골재를 개발해야 하는 특수성 때문이다.

시도별로 보면 경상북도의 채취장이 149 개소로 가장 많으며, 경기도 135 개소, 강원도 113 개소, 경상남도 92 개 


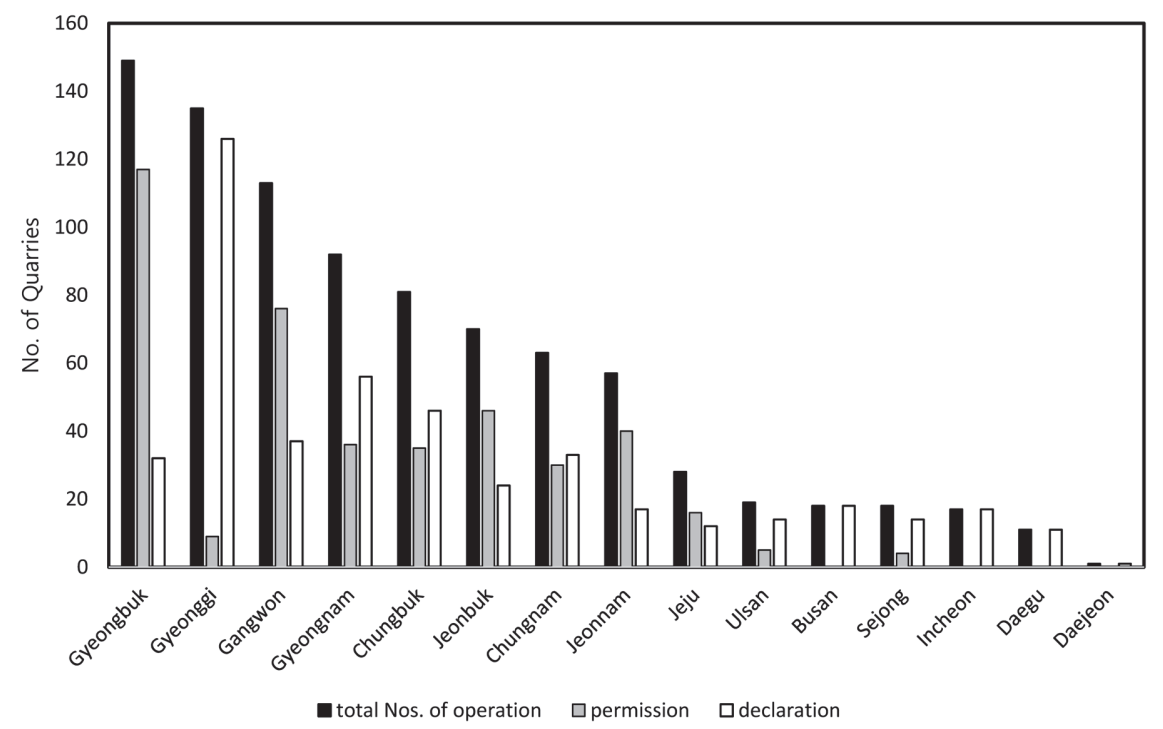

Fig. 3. The number of operation of permission and declaration, by the provinces.

소, 충청북도 81 개소, 전라북도 70 개소, 충청남도 63 개소 등이다(Fig. 3). 허가와 신고형태로 분류하면 경상북도가 허가 채취장이 가장 많은 117 개소이며, 경기도는 신고 채 취장이 가장 많은 126 개소이다. 신고보다 허가 채취장이 많은 시도는 경상북도, 강원도, 전라북도, 전라남도, 제주 도이며, 나머지 시도는 신고 채취장이 많다. 시군구별로 채취장이 20개소 이상인 지역은 2개 시군구이며, 16 20 개소는 8 개 시군구, $11 \sim 15$ 개소는 17 개 시군구, $6 \sim 10$ 개소 는 30 개 시군구, 5 개소 이하의 채취장을 운영하는 시군 구는 87 개 시군구이다.

골재원별로 보면(Fig. 4) 산림골재 채취장은 10 만 $\mathrm{m}^{3}$ 규모까지는 채취장의 수가 큰 변화를 보이지 않으며 10 만 $<20$ 만 $\mathrm{m}^{3}$ 규모에서 가장 큰 피크를 보인다. 이러한 현상은 선별파쇄에서도 유사한 특징을 보인다. 육상골재 는 2 만 $\mathrm{m}^{3}$ 미만의 채취장이 가장 많으며, 규모가 큰 채 취장은 감소하는 추세를 보인다. 채취규모는 채취장의 수 와 비슷한 경향을 나타내지만 100 만 150 만 $\mathrm{m}^{3}$ 규모에서 또 다른 피크를 보인다. 따라서 국내에서 운영되는 채취 장은 거의 대부분 약 40 만 $\mathrm{m}^{3}$ 미만의 규모를 보이지만 이들 내에서도 10 만 20 만 $\mathrm{m}^{3}, 4$ 만 $\mathrm{m}^{3}$ 미만의 채취장의 수가 가장 많으며, 채취장의 수는 매우 적지만 100 만 150 만 $\mathrm{m}^{3}$ 규모의 채취량이 10 만 20 만 $\mathrm{m}^{3}$ 규모의 채취량과 거의 유사한 것이 특징이다. 또한 10 만 $\mathrm{m}^{3}$ 미만의 채취 장 수는 전체 채취장 수의 약 $61 \%$ 를 차지할 만큼 많지 만 채취량은 전체 채취량의 약 $14 \%$ 에 불과하다.

300 만 $\mathrm{m}^{3}$ 이상의 골재를 채취한 채취장은 전체 채취장 중 1곳이다(Table 3). 100 만 200만 $\mathrm{m}^{3}$ 를 채취한 채취장 은 16 개소, 50 만 100 만 $\mathrm{m}^{3}$ 를 채취한 채취장은 44 개소이
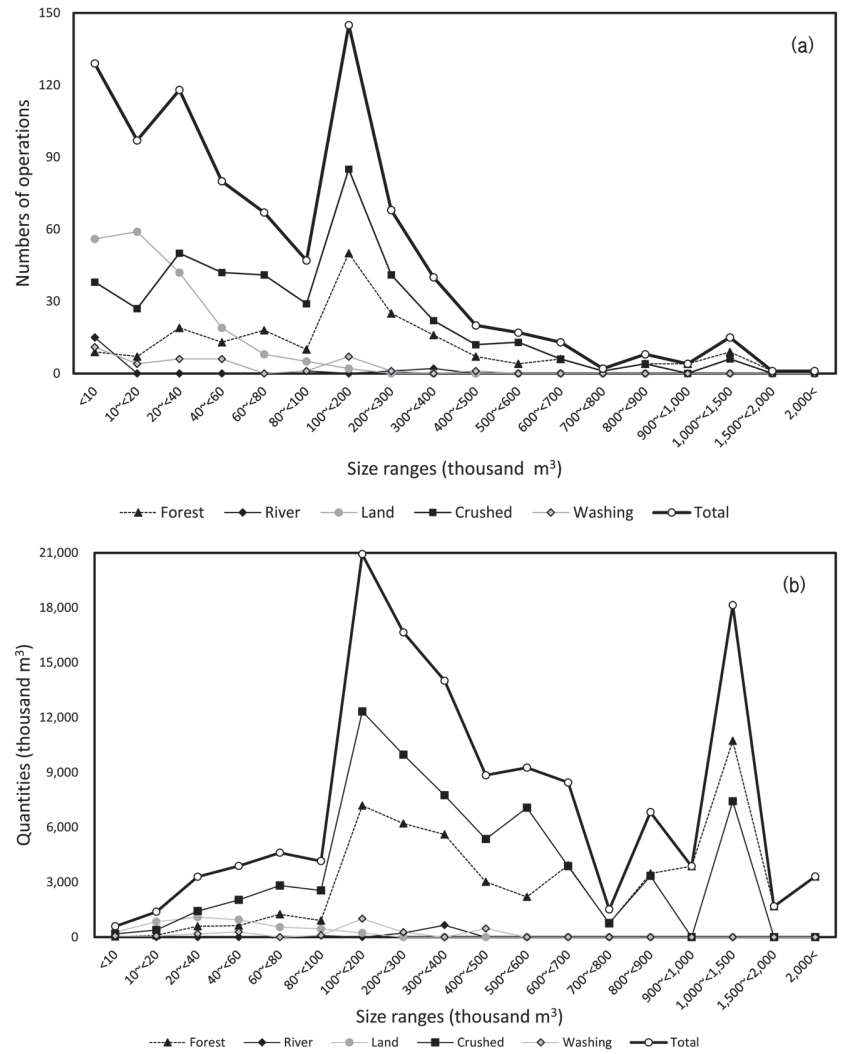

Fig. 4. The numbers of operation and quantities by size of operation.

며, 40 만 50 만 $\mathrm{m}^{3}$ 의 골재를 채취한 채취장은 20 개소로 40만 $\mathrm{m}^{3}$ 이상의 골재를 채취한 채취장은 2019년 골재 채 취장 수의 $10 \%$ 정도에 불과하지만 채취량은 거의 $50 \%$ 를 점하고 있다(Table 3). 이는 골재를 채취하는 시군에 
Table 3. Aggregate production in Korea in 2019, by source and size of operation

\begin{tabular}{|c|c|c|c|c|c|c|c|c|c|c|c|c|}
\hline \multirow{2}{*}{$\begin{array}{c}\text { size range } \\
\left(\text { thousand } \mathrm{m}^{3}\right)\end{array}$} & \multicolumn{2}{|c|}{ Foreset aggregate } & \multicolumn{2}{|c|}{ River aggregate } & \multicolumn{2}{|c|}{ Land aggregate } & \multicolumn{2}{|c|}{ Crushed aggregate } & \multicolumn{2}{|c|}{ Washing aggregate } & \multicolumn{2}{|c|}{ All aggregate } \\
\hline & $\begin{array}{l}\text { number of } \\
\text { operations }\end{array}$ & uantities & $\begin{array}{l}\text { number of } \\
\text { operations }\end{array}$ & ntities & $\begin{array}{l}\text { number of } \\
\text { operations }\end{array}$ & antities & $\begin{array}{l}\text { number of } \\
\text { operations }\end{array}$ & uantities & $\begin{array}{l}\text { number of } \\
\text { operations }\end{array}$ & antities & $\begin{array}{l}\text { number of } \\
\text { operations }\end{array}$ & uantities \\
\hline less than 10 & 9 & 36 & 15 & 47 & 56 & 272 & 38 & 171 & 11 & 56 & 129 & 582 \\
\hline $10 \sim<20$ & 7 & 101 & 0 & 0 & 59 & 841 & 27 & 379 & 4 & 57 & 97 & 1,378 \\
\hline $20 \sim<40$ & 19 & 583 & 0 & 0 & 42 & 1,087 & 50 & 1,422 & 6 & 174 & 118 & 3,295 \\
\hline $40 \sim<60$ & 13 & 626 & 0 & 0 & 19 & 949 & 42 & 2,030 & 6 & 283 & 80 & 3,887 \\
\hline $60 \sim<80$ & 18 & 1,245 & 0 & 0 & 8 & 544 & 41 & 2,818 & 0 & 0 & 67 & 4,607 \\
\hline $80 \sim<100$ & 10 & 904 & 1 & 81 & 5 & 447 & 29 & 2,544 & 1 & 93 & 47 & 4,152 \\
\hline $100 \sim<200$ & 50 & 7,185 & 0 & 0 & 2 & 228 & 85 & 12,324 & 7 & 1,004 & 145 & 20,931 \\
\hline $200 \sim<300$ & 25 & 6,206 & 1 & 218 & 0 & 0 & 41 & 9,968 & 1 & 266 & 68 & 16,658 \\
\hline $300 \sim<400$ & 16 & 5,603 & 2 & 654 & 0 & 0 & 22 & 7,754 & 0 & 0 & 40 & 14,011 \\
\hline $400 \sim<500$ & 7 & 3,022 & 0 & 0 & 0 & 0 & 12 & 5,355 & 1 & 469 & 20 & 8,846 \\
\hline $500 \sim<600$ & 4 & 2,195 & 0 & 0 & 0 & 0 & 13 & 7,063 & 0 & 0 & 17 & 9,258 \\
\hline $600 \sim<700$ & 6 & 3,927 & 0 & 0 & 0 & 0 & 6 & 3,874 & 0 & 0 & 13 & 8,445 \\
\hline $700 \sim<800$ & 1 & 745 & 0 & 0 & 0 & 0 & 1 & 765 & 0 & 0 & 2 & 1,510 \\
\hline $800 \sim<900$ & 4 & 3,485 & 0 & 0 & 0 & 0 & 4 & 3,341 & 0 & 0 & 8 & 6,826 \\
\hline $900 \sim<1,000$ & 4 & 3,865 & 0 & 0 & 0 & 0 & 0 & 0 & 0 & 0 & 4 & 3,865 \\
\hline $1,000 \sim<1,500$ & 9 & 10,729 & 0 & 0 & 0 & 0 & 6 & 7,415 & 0 & 0 & 15 & 18,144 \\
\hline $1,500 \sim<2,000$ & 1 & 1,676 & 0 & 0 & 0 & 0 & 0 & 0 & 0 & 0 & 1 & 1,676 \\
\hline 2,000 and more & 1 & 3,305 & 0 & 0 & 0 & 0 & 0 & 0 & 0 & 0 & 1 & 3,305 \\
\hline total & 204 & 55,436 & 19 & 1,000 & 191 & 4,368 & & 67,224 & 37 & 2,403 & 872 & 131,376 \\
\hline
\end{tabular}

서의 개발여건의 지원과 골재업체의 채취능력을 향상시 킨다면 채취시군을 줄이고 채취량을 늘리는 형태로 골재 수급 거점 지역을 확보할 수 있다면, 즉 채취장 수가 경 감된다면 환경영향의 부담을 완화시키고 골재 생산을 보 다 효율적으로 할 수 있을 것이다. 이는 골재 개발지역 의 선택과 집중이 필요하다는 것을 의미한다.

골재채취에는 허가에 의한 골재채취와 신고에 의한 골 재채취 등 두 가지 방법이 있다. 허가는 국유지 또는 사 유지에 골재개발을 목적으로 사업을 하고자 하는 경우 필요한 절차이며, 신고는 골재개발이 목적은 아니고 도 로, 주택, 산업단지 등의 여러 개발행위를 하는데 있어 불가피하게 암반을 제거해야 하는 경우가 있는데 이렇게 제거된 암반을 골재로 활용하기 위한 절차이다. 따라서 신고골재 업체는 직접 골재를 개발하지 않으며, 다른 지 역에서 개발행위로 인해 나온 암석들을 구매하여 파쇄를 하는 것이다. 허가와 신고는 모두 골재를 생산하고자 기 간이 명시되어 있었는데 골재채취법 개정을 통해 신고는 직접 골재를 개발하는 행위가 없으므로 신고기간의 규제 를 폐지하였다. 따라서 현재는 허가에 의한 골재개발에 서만 허가기간의 규제가 남아있다. 2019년도에 골재허가 를 받은 채취장에서 허가기간이 30 년 이상인 채취장은 2 개소이며, 10 년 이상인 채취장도 55 개소이다(Fig. 5). 그

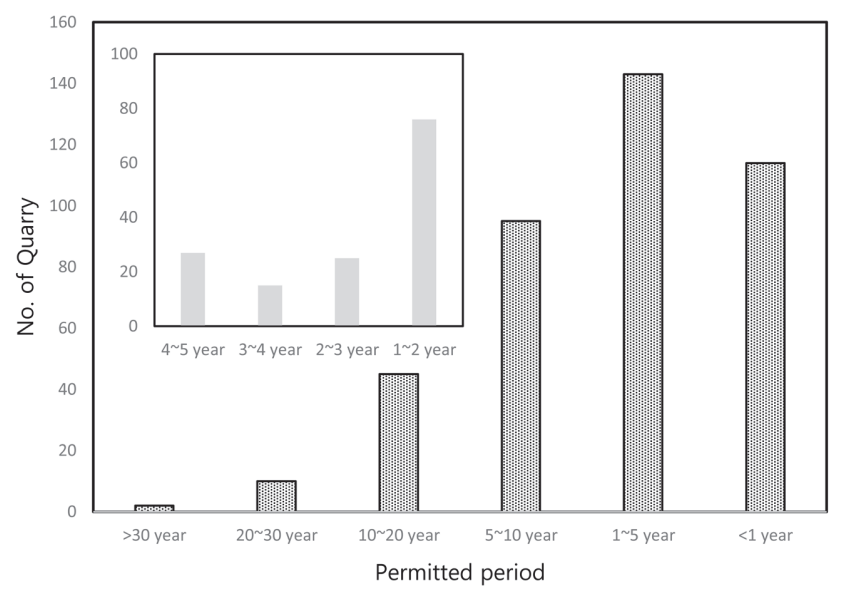

Fig. 5. The permitted periods by the operations.

러나 대부분은 5 년 이하이며, 특히 2 년 이하인 채취장은 허가 채취장의 약 $50 \%$ 정도이다.

2020년을 기준으로 골재허가가 남아 있는 채취장은 약 290개소로 2019년에 골재개발이 이루어진 채취장의 약 $1 / 3$ 은 2019년도로 허가기간이 만료되었다. 허가기간이 10 년 이상 남은 채취장은 없으며 모두 10 년 이하로 특히 허가기간 1 년 이하로 남은 채취장이 약 150 여개소로 허 
가기간이 남은 채취장의 50\%를 넘는다. 따라서 2020년 이후 원활한 골재 수급이 이루어지기 위해서는 즉, 2019 년도와 비슷한 골재물량이 공급되어야 한다는 가정을 하 면 2019년에 운영되고 있는 채취장의 약 $50 \%$ 이상이 허 가기간을 연장하거나 신규 허가를 받아야 정상적인 수요 공급이 이루어질 수 있다.

\section{5. 결 론}

이 연구에서는 2019년에 채취현황이 기록되어 있는 골 재채취장들에 대해 권역별, 골재원별, 골재형태별, 채취 규모별 특성을 파악하고자 하였다.

(1) 2019 년에는 17 개 광역시도들 중 15 개 광역시도에 서 229개 시군구들 중 147 개 시군구에서 약 872 개소의 채취장에서 골재를 채취하였다.

(2) 경상북도, 경기도, 강원도는 채취장수가 100 개소 이 상이며, 경상남도, 충청북도, 전라북도, 충청남도, 전라남 도는 50 개소 이상의 채취장이 분포한다. 그 외에 제주도 를 비롯한 광역시, 특별자치시에는 20 개소 이하의 채취 장이 분포하고 있다.

(3) 골재원별로 보았을 때 선별파쇄 골재채취장이 전체 채취장의 거의 절반을 차지하며, 산림골재, 육상골재, 선 별세척, 하천골재의 순으로 감소하지만 선별파쇄와 산림 골재의 채취장이 압도적으로 많아 골재원이 점차 선별파 쇄와 산림골재로 편중화되는 경향을 보인다.

(4) 골재 종류별로 보았을 때 자갈만 채취한 채취장 (37.6\%)이 모래만 채취한 채취장 $(47.0 \%)$ 보다 약 $10 \%$ 정 도 더 많으며, 모래와 자갈 모두 채취한 채취장은 전체 채취장의 약 $15 \%$ 이다.

(5) 채취 규모로 보았을 때 1 만 10 만 $\mathrm{m}^{3}$ 미만의 채취 장이 409개소로 가장 많지만 생산물량은 10 만 50 만 $\mathrm{m}^{3}$ 미만의 273 개소의 채취장에서 생산된 물량이 가장 많다. 50 만 $\mathrm{m}^{3}$ 이상 규모의 채취장은 전체 채취장의 $7 \%$ 에 불 과하지만 채취된 물량은 전체의 $40 \%$ 를 점한다. 이는 골 재채취시군에서 개발생산여건의 개선 및 지원, 그리고 채 취장의 채취능력을 향상시켜 채취시군을 줄이고 채취량 을 늘리는 형태로 공급거점이 확보되면 환경의 부담이 완화되고 효율적인 골재수급 가능할 것이다. 즉, 골재 개 발지의 선택과 집중이 필요하다.

(6) 400 여개소의 허가골재채취장에서 골재의 채취허가
기간은 대부분 5 년 이하이다. 산림골재의 허가기간은 5 년 이상 긴 편이나 육상, 하천골재의 허가기간은 대부분 2년 이하이다. 또한 2020년을 기준으로 허가기간이 남아 있는 채취장은 총 채취장수의 $70 \%$ 정도이며, $70 \%$ 중에 1 년 이내에 허가 만료되는 채취장이 $50 \%$ 이다. 현재와 같 은 허가골재의 공급이 유지되려면 현재 운영되는 채취장 의 약 $50 \%$ 이상이 허가기간연장 또는 신규허가를 받아 야 한다.

(7) 골재의 채취장 수와 채취물량을 비교하면 소규모 채취장은 많지만 채취물량은 적고, 대규모의 채취장은 적 지만 채취물량은 압도적으로 많은, 뚜렷한 양극화 현상 을 보인다. 따라서 향후 골재 수급은 채취장의 수와 채 취 규모를 적절히 조절하여 점차 대형화하는 방향으로 가는 것이 안정적 골재 수급에 도움이 될 것이다.

\section{사 사}

이 연구는 한국지질자원연구원에서 수행하고 있는 국 토교통부 “2021년 골재자원조사 및 관리사업(IP2021-006)" 의 지원으로 수행되었습니다. 또한 논문에 대한 세심한 검토와 제안을 해주신 심사위원 분들께 감사드립니다.

\section{References}

Hong, S.S., Kim, J.Y. and Lee, J.Y. (2015) Trends of supply and demand of aggregate in Korea(I). Jour. Petro. Soc. Korea, v.24, p.253-272. doi: 10.7854/JPSK.2015.24.3.253

Hong, S.S. and Lee, J.Y. (2019) Analysis of 2019 domestic aggregate production in Korea(I). Korea Econ. Environ. Geol., v.53, p.755-769. doi: 10.9719/EEG.2020.53.6.755

Hong, S.S. and Lee, J.Y. (2021) Analysis of 2019 domestic aggregate production in Korea(II). Korea Econ. Environ. Geol., v.54, p.427-439. doi: 10.9719/EEG.2021.54.4.427

Ministry of Land, Infrastructure and Transport (2014) The $5^{\text {th }}$ Basic plan for supply and demand of aggregate, 358p.

Ministry of Land, Infrastructure and Transport (2018) The $6^{\text {th }}$ Basic plan for supply and demand of aggregate, $368 \mathrm{p}$.

Ministry of Land, Infrastructure and Transport (2019) Annual aggregate statistics, www.agris.go.kr

Willett, J.C. (2020) Sand and gravel, construction(advance release), 2017 Minerals Yearbook, U.S. Geological Survey, 14p.

Willett, J.C. (2020) Stone, crushed(advance release), 2017 Minerals Yearbook, U.S. Geological Survey, 26p. 